\title{
Kesantunan Berbahasa Mahasiswa pada Dosen dalam Wacana Komunikasi Whatsapp di STABN Sriwijaya
}

\author{
Suntoro \\ STABN Sriwijaya, Indonesia \\ E-mail: suntoro@stabn-sriwijaya.ac.id
}

\begin{abstract}
Abstrak. Penelitian ini bertujuan untuk mengetahui kesantunan berbahasa mahasiswa pada dosen melalui Whatsapp. Metodologi penelitian yang dipakai adalah kualitatif deskriptif dengan fokus penelitian yaitu gaya bahasa dan pematuhan prinsip kesantunan berbahasa WhatsApp. Teknik pengumpulan data menggunakan dokumentasi dan teknik analisis datanya menggunakan metode normatif. Hasil penelitian ini menunjukkan bahwa gaya bahasa komunikasi mahasiswa terhadap dosen berbasis jejaring sosial WhatsApp cenderung mengabaikan kaidah tata bahasa yang benar. Dari aspek gramatikal ditemukan gejala elipsis dan kata depan unik. Pada aspek leksikal ditemukan gaya language mixing dan bahasa gaul. Pada aspek grafologi ditemukan clipping, sound addition, dan coinage. Sementara itu, dalam wacana komunikasi berbasis jejaring sosial WhatsApp mahasiswa mampu mematuhi prinsip kesantunan berbahasa meliputi prinsip kebijaksanaan, kedermawanan, penghargaan, kesederhanaan, kecocokan, dan kesimpatian. Meskipun demikian, juga ditemukan pelanggaran-pelanggaran terhadap prinsip kesantunan berbahasa komunikasi berbasis jejaring sosial WhatsApp.
\end{abstract}

Kata Kunci: kesantunan berbahasa; komunikasi WhatsApp

\section{PENDAHULUAN}

Pada akhir tahun 2017 media daring sempat diramaikan oleh pemberitaan mengenai etiket menghubungi dosen melalui telepon genggam yang dikeluarkan Universitas Indonesia (UI). Salah satu isi dari etika tersebut adalah imbauan menggunakan bahasa indonesia yang baik dalam situasi formal termasuk di antaranya larangan menggunakan singkatan. Seperti dikutip dari laman beritagar.id, Riffely Dewi Astuti selaku Kepala Humas UI menegaskan bahwa etiket tersebut adalah imbauan, bukan aturan (https://beritagar.id/artikel/gaya-hidup/etiket-mahasiswa terhadap-dosen). Namun, etiket tersebut bisa jadi merupakan akibat dari akumulasi pelanggaran-pelanggaran yang dilakukan oleh mahasiswa ketika menghubungi dosen.

Sebelum pemberitaan etiket menghubungi dosen di UI viral, pemberitaan mengenai ketidaksantunan mahasiswa ketika menghubungi dosen juga banyak terjadi. Salah satunya seperti yang diunggah di media online merdeka.com. "Pak. maaf sy telat kirim tugas soalnya kmrn enggak masuk. tugas saya kirim ke email yah." Pesan mahasiswa pada dosen. "Saya hanya menerima tugas dalam bentuk print out supaya mudah saya baca" Jawab dosen. "Emang kenapa kalau email. Kan irit kertas?" Jawab mahasiswa tersebut seolah membenarkan bahwa generasi muda sudah kehilangan sopan santun dalam berkomunikasi dengan orang yang lebih tua, dalam hal ini adalah dosen (https://www.merdeka.com/peristiwa/sms- kurang-ajar-mahasiswa-ke-dosen-bikin-kita-senyumsenyum.html).

Psikolog UI, Bona Sardo menilai gaya bahasa yang berubah terjadi karena semakin intensifnya generasi muda bermedia sosial. Kosa kata ala milenial yang sangat sederhana, serba cepat, dan efisien merupakan produk penggunaan media sosial. Akhirnya, cara berkomunikasi dengan teman sebaya terbawa saat berkomunikasi dengan para dosen yang usianya lebih tua. Generasi milenial yang lahir bersama internet (net generation) memiliki sifat cenderung instan dan ingin segala sesuatunya cepat dan mendesak. Penggunaan singkatan dalam berkirim pesan merupakan penanda net generation ini.

Kemudahan berkomunikasi yang ditawarkan oleh jejaring sosial seperti WhatsApp hendaknya tidak mengebiri etika berkomunikasi. Wahyudin dan Karimah (2010:1) komunikasi di media sosial cenderung mengabaikan hal-hal yang fundamental dalam komunikasi: penghormatan kepada orang lain, empati kepada lawan bicara, dan antisipasi atas dampak-dampak ujaran atau pernyataan. Pendapat tersebut juga didukung oleh pendapat Watie yang mengatakan bahwa kehadiran internet yang diikuti dengan munculnya media sosial di dalamnya membawa pula berbagai masalah etika berkomunikasi (Watie, 2011:72). Terlebih jika sarana yang dipakai menggunakan bahasa tulis yang sangat dipengaruhi oleh tanda baca dan ejaan serta ketidaklengkapan unsur gramatikal dapat menyebabkan perbedaan penafsiran. 
Dalam dunia akademik di perguruan tinggi, kesantuan berbahasa seharusnya menjadi ciri khas bagi sivitas akademika. Tutur dan santun bahasa dapat menjadi cerminan keakademisan seseorang. Kesantunan berbahasa merujuk pada cara yang digunakan oleh penutur di dalam berkomunikasi agar mitratutur tidak merasa tertekan, tersudut, atau tersinggung (Markhamah, 2011:153). Brown dan Levinson (2010:2) kesantunan berbahasa dimaknai sebagai usaha penutur untuk menjaga harga diri, atau wajah, penutur atau pendengar. Artinya dalam berbahasa, seseorang harus mampu menghargai mitratutur. Leech (2015:9) kesantunan berbahasa adalah kesopanan dan kehalusan dalam menggunakan bahasa ketika berkomunikasi melalui lisan maupun tulisan. Kesantunan juga sering dianggap sebagai fenomena kulural karena apa yang dianggap santun oleh suatu kultur belum tentu juga santun oleh kultur lainnya. Oleh karena itu, Rahardi (2005:35) kesantunan berbicara selalu bersinggungan dengan latar belakang situasi sosial dan budaya yang mewadahinya.

Ada banyak prinsip yang harus dipenuhi untuk dapat dikatakan santun berbahasa. Leech (2015:206-207) mengemukakan ada enam maksim kesantunan berbahasa antara lain maksim kebijaksanaan, kedermawanan, penghargaan, kesederhanaan, kecocokan, dan kesimpatian. Brown dan Levinson membagi prinsip kesantunan berbahasa berdasarkan nosi muka, yaitu muka positif dan muka negatif. Sementara itu, Lakoff mengemukakan ada tiga kaidah yang harus ditaati agar tuturan dianggap santun yaitu kaidah formalitas, ketidaktegasan, dan persamaan. Kajian penelitian ini menggunakan skala kesantunan Leech sebagai dasar penentuan kesantunan berbahasa.

Secara khusus, Leech juga menguraikan parameter/skala kesantunan yang meliputi: (1) skala kerugian dan keuntungan menunjuk kepada besar kecilnya kerugian dan keuntungan yang diakibatkan oleh sebuah tindak tutur pada sebuah tuturan; (2) skala pilihan menunjuk kepada banyak atau sedikitnya pilihan (options) yang disampaikan si penutur kepada si mitra tutur di dalam kegiatan bertutur; dan (3) skala ketidaklangsungan menunjuk kepada peringkat langsung atau tidak langsungnya maksud sebuah tuturan. Ketiga skala tersebut terkait erat dengan lima prinsip kesantunan berbahasa yang diperkenalkan oleh Leech.

Potret kesantunan berbahasa mahasiswa pada dosen di Sekolah Tinggi Agama Buddha Negeri Sriwijaya (STABN Sriwijaya) dalam komunikasi WhatsApp secara umum cukup baik. Meskipun demikian, pelanggaran kesantunan berbahasa juga banyak terjadi. Menurut pengamatan peneliti, faktor utama penyebab terjadinya pelanggaran kesantunan berbahasa melalui WhatsApp adalah kedekatan. Tak bisa dipungkiri, hubungan dosen dan mahasiswa di STABN Sriwijaya cukup dekat dan cenderung akrab. Hal inilah yang dapat membuat mahasiswa terkadang tidak mampu membedakan konteks percakapan dalam ranah formal (akademik) atau nonformal (di luar akademik).

Penggunaan WhatsApp sebagai media komunikasi di satu sisi sangat menguntungkan. Di sisi lain, penggunaan WhatsApp bisa jadi sangat merugikan jika tidak disikapi secara bijak. WhatsApp menawarkan berbagai fitur untuk berkomunikasi, tidak hanya teks, tetapi juga gambar dan emoticon. Oleh karena itu, pesan WhatsApp memiliki medan interpretasi yang sangat terbuka karena keberadaan fitur-fitur tersebut. Hal tersebut senada dengan pendapat Hermawan (2016:22) yang mengatakan bahwa "gambar dapat dipandang sebagai bahasa verbal sehingga dapat dianalisis dengan langkah-langkah yang jelas." Pertama, kita harus memperlakukan gambar (emoticon dalam hal ini) sebagai bahasa. Emoticon diyakini sebagaimana bahasa verbal merupakan representasi pengalaman. Ketika menganalisis emoticon kita harus memperhatikan hubungan yang tercipta antara pembuat, yang melihat, dan objek dalam gambar. Kedua, melakukan penggambaran atau identifikasi terhadap makna emoji dalam wacana percakapan berbasis jejaring sosial WhatsApp.

Kajian mengenai kesantunan berbahasa telah banyak dilakukan, namun sebagian besar bahan kajiannya masih seputar bahasa lisan dan tulis secara umum. Penelitian Fahmi Gunawan (2013) misalnya mengemukakan bahwa Mahasiswa menggunakan beragam cara untuk menunjukkan kesantunan berbahasa. Kalimat deklaratif dan interogatif digunakan untuk menyatakan kesantunan, sedangkan kalimat imperatif digunakan untuk menyatakan perintah. Selain itu, mahasiswa juga menggunakan kalimat lengkap untuk menunjukkan kesopanan. Sementara itu penelitian Iswah Adriana (2013) mengenai kesantunan berbahasa melalui sms ditemukan fakta bahwa seluruh data sms mahasiswa berkaitan erat dengan kegiatan perkuliahan seperti permintaan waktu konsultasi, penjelasan tugas, dan pengecekan kehadiran. Dari 27 teks yang yang ada, sebanyak 4 teks termasuk kategori mematuhi kesantunan, 5 teks melanggar kesantunan, 9 teks masuk dalam kategori cukup santun, dan 9 teks lainnya tidak santun.

Penelitian mengenai kesantunan berbahasa mahasiswa pada dosen dalam wacana komunikasi WhatsApp di STABN Sriwijaya sangat menarik karena selain menyajikan teks, WhatsApp juga menyajikan gambar dan emoticon yang memungkinkan terjadinya keterbukaan interpretasi. Selain itu, faktor kedekatan mungkin juga turut memengaruhi kualitas kesantunan berbahasa mahasiswa pada dosen. Hasil penelitian ini diharapkan dapat memberi penjelasan mengenai gaya bahasa WhatsApp dan potret kesantunan berbahasa mahasiswa di STABN Sriwijaya.

\section{METODE}

Penelitian ini menggunakan pendekatan kualitatif deskriptif. Penelitian ini dilaksanakan di STABN Sriwijaya Tangerang selama bulan Februari sampai Juli 2018 dengan teknik pengambilan data menggunakan dokumentasi. Data yang didokumentasikan adalah pesan Whatsapp mahasiswa kepada dosen atau sebaliknya yang terkumpul sebanyak 89 data. Analisis data menggunakan metode normatif dengan mencocokkan data yang berpedoman pada kriteria prinsip kesantunan (Adriana 2014:55). Kriteria pematuhan kesantunan berbahasa menggunakan indikator pematuhan kesantunan berbahasa Leech. 
TABEL 1

INDIKATOR PEMATUHANAN PRINSIP KESANTUNAN BERBAHASA (LEECH, TERJEMAHAN OKA 2015)

\begin{tabular}{|c|c|c|c|c|}
\hline No. & Maksim & & Indikator & Subindikator \\
\hline \multirow[t]{5}{*}{1} & \multirow[t]{5}{*}{ Kebijaksanaan } & \multirow[t]{2}{*}{$(+)$} & Memperbesar & Menawarkan sesuatu yang menguntungkan orang lain \\
\hline & & & $\begin{array}{l}\text { keuntungan orang } \\
\text { lain }\end{array}$ & $\begin{array}{l}\text { Tawaran berilokusi hasil positif berupa keuntungan untuk benda atau materi, nama baik, } \\
\text { prestasi, penghargaan, dan kenyamanan kepada orang lain. }\end{array}$ \\
\hline & & \multirow[t]{3}{*}{$(-)$} & Memperkecil & Menggunakan strategi ketaklangsungan untuk tidak menuntut adanya respons langsung \\
\hline & & & kerugian orang lain & $\begin{array}{l}\text { yang berupa tindakan orang lain yang dapat berupa bentuk anjuran, nasihat, atau impositif; } \\
\text { Menggunakan kalimat tanya untuk mengungkapkan suatu perintah; }\end{array}$ \\
\hline & & & & Memberikan suatu informasi yang tidak merugikan orang lain. \\
\hline \multirow[t]{5}{*}{2} & \multirow[t]{5}{*}{ Kedermawanan } & \multirow[t]{3}{*}{$(+)$} & Memperbesar & Memberikan suatu tawaran yang leluasa kepada orang lain; \\
\hline & & & kerugian diri & Memberikan suatu tawaran yang leluasa kepada orang lain; \\
\hline & & & sendiri & $\begin{array}{l}\text { Memberikan sesuatu yang menghasilkan efek berupa tindakan diri sendiri, misalnya berupa } \\
\text { memberikan doa yang baik. }\end{array}$ \\
\hline & & \multirow[t]{2}{*}{$(-)$} & $\begin{array}{l}\text { Memperkecil } \\
\text { keuntungan diri }\end{array}$ & $\begin{array}{l}\text { Melakukan sesuatu yang menghasilkan efek berupa tindakan diri sendiri (pada ilokusi } \\
\text { impositif) yang dapat berupa bersikap peduli dan bersifat kemurahan hati; }\end{array}$ \\
\hline & & & sendiri & $\begin{array}{l}\text { Bersikap membantu dan menghormati orang lain dengan memberikan saran atau } \\
\text { nasihat yang baik. }\end{array}$ \\
\hline \multirow[t]{3}{*}{3} & \multirow[t]{3}{*}{ Penghargaan } & $(+)$ & $\begin{array}{l}\text { Memperbesar } \\
\text { pujian orang lain }\end{array}$ & $\begin{array}{l}\text { Memberikan pujian yang tulus kepada orang lain yang dapat berupa mengagumi, } \\
\text { menghormati, dan tidak merendahkan; } \\
\text { Memberikan penghargaan kepada orang lain. }\end{array}$ \\
\hline & & \multirow[t]{2}{*}{$(-)$} & Memperkecil & Tidak mengatakan hal-hal yang tidak menyenangkan kepada orang lain; \\
\hline & & & kecaman orang lain & Tidak mencaci, mencela, dan memfitnah orang lain. \\
\hline \multirow[t]{4}{*}{4} & \multirow[t]{4}{*}{ Kesederhanaan } & \multirow[t]{2}{*}{$(+)$} & Memperbesar & Menunjukkan kelemahan diri sendiri; \\
\hline & & & kecaman diri sendiri & Bersikap rendah hati dan mengurangi pujian diri sendiri. \\
\hline & & \multirow[t]{2}{*}{$(-)$} & Memperkecil pujian & Tidak memamerkan kelebihan dirinya sendiri pada orang lain; \\
\hline & & & diri sendiri & Tidak menyombongkan diri sendiri mengenai pengetahuan yang dimilikinya. \\
\hline \multirow[t]{3}{*}{5} & \multirow[t]{3}{*}{ Kecocokan } & $(+)$ & $\begin{array}{l}\text { Memperbesar } \\
\text { persesuaian diri } \\
\text { sendiri dan orang lain }\end{array}$ & $\begin{array}{l}\text { Memaksimalkan kesepakatan atau kesetujuan antara diri sendiri dan orang lain dengan } \\
\text { memberikan pendapat yang dapat disertai contoh dan mengedepankan pokok pembicaraan }\end{array}$ \\
\hline & & \multirow[t]{2}{*}{$(-)$} & $\begin{array}{l}\text { Memperkecil } \\
\text { ketidaksesuaian diri }\end{array}$ & $\begin{array}{l}\text { Menghindari pendapat yang bertolak belakang terhadap topik pembicaraan dengan cara } \\
\text { tidak mencampuradukkan pokok masalah yang sedang dibicarakan; }\end{array}$ \\
\hline & & & sendiri dan orang lain & $\begin{array}{l}\text { Menghindari kepentingan yang tidak ada hubungannya dengan pokok masalah yang } \\
\text { dibicarakan dengan cara memberikan pendapat, usulan, atau kritik. }\end{array}$ \\
\hline \multirow[t]{4}{*}{6} & \multirow[t]{4}{*}{ Kesimpatian } & $(+)$ & Memperbesar simpati & $\begin{array}{l}\text { Ikut serta merasakan perasaan orang lain dalam bentuk memberikan ucapan selamat; } \\
\text { Timbul berdasarkan penilaian perasaan dari diri sendiri kepada orang lain. }\end{array}$ \\
\hline & & \multirow[t]{3}{*}{$(-)$} & Memperkecil antipati & Menahan untuk tidak meniadakan pergaulan antarorang; \\
\hline & & & & Bersikap senang kepada orang lain; \\
\hline & & & & Terampil memahami perasaan orang lain. \\
\hline
\end{tabular}

Uji validitas yang digunakan dalam penelitian ini adalah validitas pragmatik, yaitu untuk melihat seberapa jauh data yang dapat dianalisis sesuai dalam konteks tuturan. Uji realibilitas pada penelitian ini menggunakan uji reliabilitas intrarater, maksudnya adalah dengan membaca dan meneliti objek dengan berulang-ulang sampai mendapatkan data yang dimaksud. Seperti yang dijelaskan Moleong (2013:177-180) uji reabilitas ini membutuhkan ketekunan pengamatan penelitinya. Selain itu, juga digunakan realibilitas interater, yaitu mendiskusikan hasil penelitian dengan teman sejawat yang dianggap mempunyai kemampuan intelektual dan kapasitas linguistik yang cukup bagus.

\section{HASIL DAN PEMBAHASAN}

Hasil penelitian ini menunjukkan bahwa wacana komunikasi mahasiswa pada dosen menggunakan WhatsApp dari apek gaya bahasa banyak dijumpai penggunaan bahasa yang tidak sesuai kaidah. Ketidaksesuaian tersebut muncul dalam aspek gramatikal, leksikal, dan grafologi. Sementara itu, secara umum bahasa yang digunakan mahasiswa untuk berkomunikasi dengan dosen sudah memenuhi prinsip kesantunan, meskipun juga terdapat beberapa pelanggaran kesantunan berbahasa di dalamnya.

\section{Gaya Bahasa WhatsApp Mahasiswa}

Gaya bahasa WhatsApp mahasiswa kepada dosen dapat dianalisis dari tiga aspek yaitu gramatikal, leksikal, dan grafologinya. Analisis mengenai gaya bahasa ini dapat dilakukan dengan cara membandingkan pesan WhatsApp dengan gaya konvensional (gaya yang berlaku umum atau seharusnya). Berikut adalah beberapa temuan terkait gaya bahasa WhatsApp mahasiswa dari aspek gramatikal, leksikal, dan grafologinya.

1. Aspek gramatikal

Pada aspek gramatikal terdapat dua fenomena gaya bahasa WhatsApp mahasiswa yaitu ellipsis dan konjungsi unik.

a) Elipsis

Salah satu penanda kohesi aspek gramatikal dalam sebuah kalimat adalah elipsis (pelesapan). Potensi terjadinya elipsis pada bahasa WhatsApp jauh lebih besar dibandingkan wacana tulis lain semisal surat atau berita. Kecenderungan untuk memproduksi bahasa secara singkat dan padat merupakan faktor utama penyebab terjadinya elipsis. Berikut adalah contoh fenomena elipsis yang muncul dalam wacana komunikasi mahasiswa terhadap dosen berbasis jejaring sosial WhatsApp. 
[1a] Selamat malam mrs puji. Namo Buddhaya. Mrs ini devi. Mau tanya gelarnya bu aikim sama pak sarjono apa ya mrs? (gaya WhatsApp)

[1b] Selamat malam Mrs Puji, Namo Buddhaya. Mrs ini devi. (Saya) mau bertanya apa gelar Bu Aikim dan Pak Sarjono? (gaya konvensional)

[2a] Namo buddhaya pak, Pak, boleh pinjem lab. komputer? (gaya WhatsApp)

[2b] Namo buddhaya Pak. Pak, (apakah saya) boleh pinjam lab. komputer? (gaya konvensional)

Pelesapan subjek dalam wacana 1a dan $2 \mathrm{a}$ adalah penanda yang paling mudah dikenali dalam bahasa WhatsApp. Pelesapan memang berfungsi untuk menghemat karakter dalam wacana tulis menggunakan jejaring sosial WhatsApp. Meskipun terjadi pelesapan, maksud dari pesan dalam bahasa WhatsApp umumnya dapat dimengerti oleh pembacanya.

b) Kata depan unik

Kata depan unik yang ditemukan dalam penelitian ini berbentuk clipping yaitu satu huruf untuk mewakili satu kata depan. Fungsi kata depan dalam satuan gramatikal pesan sangat vital karena kata depan dapat digunakan sebagai penanda tujuan/maksud atau keterangan dalam pesan tersebut. Ada dua jenis kata depan unik yang digunakan oleh mahasiswa yaitu $\mathbf{k}$ untuk mewakili kata depan ke dan d yang digunakan untuk mengganti kata depan di. Berikut adalah penggunaan kata depan unik yang digunakan oleh mahasiswa dalam pesan WhatsApp kepada dosen.

[3] Mau bawa k ruangan Bapak???

[4] Saya liat d persyaratannya wajib buat power point kan?

\section{Aspek leksikal}

a) Language mixing

Language mixing adalah fenomena bercampunya dua atau lebih bahasa dalam sebuah ujaran lisan maupun tulis. Language mixing dalam penelitian ini terjadi karena adanya percampuran antara bahasa Indonesia dan bahasa asing (Inggris) serta bahasa daerah (Tangerang). Berikut adalah beberapa language mixing yang terjadi dalam wacana komunikasi berbasis WhatsApp antara mahasiswa dan dosen.

[5] Haduhhh perlu jasa yah pak buat diteliti

[6] Suruh observasi ke vihara-vihara dengan basic beda beda

[7] Saya mau lanjut lampiran dulu Pak. Nanti next lagi

Pada data 5 terjadi language mixing dengan bahasa daerah (Tangerang) yaitu "jasa" yang bermakna "sangat". Sementara pada wacana 6 dan 7 language mixing terjadi antara bahasa Indonesia dan Inggris pada kata "basic" yang bermakna "latar belakang" serta kata "next" yang bermakna "selanjutnya". Penggunaan language mixing dalam bahasa WhatsApp merupakan pengaruh dari bahasa lisan yang dalam keseharian digunakan oleh mahasiswa.

b) Bahasa gaul

Bahasa gaul dalam penelitian ini merujuk pada bahasa komunikasi sehari-hari, bukan bahasa formal, dan biasanya merupakan hasil imitasi dari istilah di televisi melalui sinetron dan tayangan lainnya. Berikut adalah beberapa contoh bahasa gaul yang digunakan mahasiswa untuk berkomunikasi dengan dosen menggunakan jejaring sosial WhatsApp.

\section{[8] Cemungut}

[9] Iyehh masama

[10] Oke mrs otw

[11] Pilihlah doang

Makna kata "cemungut" pada wacana di atas merupakan bahasa gaul dari kata "semangat". Kata "Iyehh masama" merupakan pengaruh dialek Betawi yang memiliki makna "Ya, sama-sama". Kata "otw" diambil dari kata "on the way" yang dalam konteks percakapan sehari-hari dalam bahasa Indonesia dimaknai "sedang di jalan", sementara kata "doang" bermakna "itu saja".

Dari sisi leksikal bahasa WhatsApp yang digunakan mahasiswa mencerminkan bahasa lisan keseharian mereka. Bahasa tulis dalam wacana komunikasi mahasiswa dengan dosen merupakan bentuk pengalihan bahasa lisan keseharian ke dalam bahasa tulis. Perkembangan teknologi informasi memang memudahkan mahasiswa dalam mengakses istilahistilah baru yang muncul dalam wacana komunikasi. Oleh karena itu, munculnya proses campur kode dan bahasa gaul tidak dapat dihindarkan.

3. Aspek grafologi

a) Clipping

Clipping adalah sebuah fenomena pemotongan atau pemendekan bahasa dengan cara menghilangkan sebagian vokal dan/atau konsonan atau mengganti vokal dan/atau konsonan dengan tujuan untuk menghemat kata. Hampir semua data percakapan mahasiswa dan dosen melalui jejaring sosial WhatsApp dalam penelitian ini mengandung unsur clipping. Clipping dapat terjadi pada tataran kata maupun frasa. Contoh clipping pada tataran kata seperti lab (laboratorium), dgn-dg (dengan), hrus (harus), sy-sya (saya), td (tadi), ni (ini), nnti (nanti), mlm (malam), kalo-kl (kalau), blum (belum), bls (balas), bru (baru), aja (saja), jgn (jangan), yg (yang), aq (aku), brp (berapa), gimana-gmna (bagaimana), tdk (tidak), dd (dharmaduta), sdg (sedang), sdh (sudah), trus (terus), dri (dari), kn (kan), bru (baru), mlm (malam), slmt (selamat), dl (dinas luar), km (kami), dan blm (belum).

Sementara itu pada tataran gabungan kata, clipping yang muncul seperti gws (get well soon), ppt (power point), otw (on the way), tks (terima kasih), pg (pilihan ganda), NB (Namo Buddhaya), dll (dan lain-lain), dan DD (Dharmaduta). Clipping yang digunakan mahasiswa umumnya tidak sesuai dengan kaidah penulisan akronim atau singkatan yang berlaku. Meskipun demikian, tidak terjadi perbedaan penafsiran atau kesulitan dalam memahami maksud ujaran baik itu oleh dosen maupun mahasiswa. Hal ini membuktikan bahwa fenomena clipping merupakan gejala yang sudah bersifat umum dan telah disepakati bersama meskipun tidak pernah dituliskan.

\section{b) Sound addition}

Sound addition merupakan penambahan huruf pada akhir kata untuk memberikan efek tertentu pada kata tersebut. Efek tersebut dapat bertujuan untuk penegasan atau sekadar memberi gaya pada tulisan. Gejala sound addition dalam penelitian ini dapat ditemukan pada data berikut.

[12] Ooo ok Miss gws yah buat Anjali $:-\mathbb{A}$

[13] Seperti ini teruss

[14] Oiyaaaa kan masih 3 pertemuan 
c) Coinage

Coinage adalah penemuan sebuah simbol yang dianggap dapat mewakili sebuah kata. Simbol tersebut dapat berupa huruf atau ikon tertentu dan seperti clipping, coinage sudah dipahami baik oleh penutur maupun mitratutur. Berikut adalah contoh coinage yang muncul dalam wacana komunikasi mahasiswa pada dosen berbasis jejaring sosial WhatsApp.

[15] Iyh Miss km GX pake flash

[16] 3 lusin pak, ya pokokny dri ank" semester satu sampai semester 5 pak

Penemuan simbol GX untuk mengganti kata "tidak" merupakan bentuk coinage yang berbentuk huruf. Sementara itu, penggunaan coinage "ank" " untuk menggantikan kata ulang "anak-anak" merupakan penemuan baru karena umumnya untuk mewakili perulangan kata coinage yang umum dipakai adalah "angka 2" seperti pada kata "anak2" yang merujuk pada ejaan Soewandi.

Beragamnya bahasa WhatsApp mahasiswa dari sisi grafologi merupakan proses pembiasaan yang telah berlangsung lama dan dibawa dalam ranah akademik. Umumnya para mahasiswa meniru model yang telah ada sebelumnya dan menjadikan model tersebut sebagai contoh komunikasi. Selain itu, munculnya gejala clipping, sound addition, maupun coinage dalam wacana komunikasi menggunakan WhatsApp mengindikasikan mahasiswa ingin membangun komunikasi seefektif mungkin. Padahal, pengiriman pesan melalui WhatsApp tidak dibatasi jumlah karakter seperti pada Short Massage System (SMS).

\section{Pematuhan Kesantunan Berbahasa Mahasiswa}

Pematuhan kesantunan berbahasa mahasiswa kepada dosen dalam wacana komunikasi berbasis jejaring sosial WhatsApp dapat dilihat dari ketaatan komunikasi pada prinsip-prinsip kesantunan yang berlaku. Beberapa prinsip kesantunan yang dapat dijadikan indikator dalam menentukan pematuhan kesantunan berbahasa mahasiswa antara lain prinsip kebijaksanaan, kedermawanan, penghargaan, kesederhanaan, kecocokan, dan kesimpatian.

\section{a. Pematuhan Prinsip Kebijaksanaan}

Pematuhan kesantunan berbahasa terhadap prinsip kesantunan dalam wacana komunikasi berbasis jejaring sosial WhatsApp ditandai dengan upaya untuk memperbesar keuntungan bagi orang lain atau lawan bicara dan memperkecil kerugian orang lain atau lawan bicara. Terkait pematuhan terhadap prinsip kebijaksanaan terdapat lima belas wacana komunikasi yang menunjukkan adanya upaya mahasiswa untuk memperbesar keuntungan bagi dosen. Berikut adalah beberapa bentuk komunikasi antara mahasiswa dan dosen yang menunjukkan adanya pematuhan terhadap prinsip kebijaksanaan.

[17] Mahasiswa : "Siang miss,, Miss anna, sya boleh minta ppt materi yang kemarin?"

Dosen

[18] Mahasiswa : "Selamat pagi pak, nammp buddhaya, maaf mengganggu waktunya pak, saya ingin mengkonfirmasi tiket talkshow hari ini, untuk tiketnya langsung $d$ ambil $d$ lokasi acaranya hari ini atau gmna pak, terimakasih nammo buddhaya."

\section{Dosen} : "Ini jawaban panitia talkshow Yani)."

[19] Mahasiswa : "Selamat siang bu, nammo buddhaya, saya sudah confirm untuk jadwal pengisi kebaktian umum d dhammaphala, ternyata untuk bulan april dan mei ini sudah full, juni gmana bu? Terimakasih."

Dosen : "Ya, bolehlah! Katakan bahwa ini program promosi yah!"

Pada wacana percakapan 16 terlihat bahwa mahasiswa bermaksud meminta power point kepada dosen yang disampaikan dengan bahasa yang santun. Ungkapan permintaan akan memiliki nilai rasa lebih sopan jika disampaikan dengan permohonan izin yang ditandai dengan kata "boleh". Nilai rasa kesopanan pada ungkapan tersebut tentu berbeda jika disampaikan dalam bentuk kalimat "sya minta ppt materi yang kemarin?". Ungkapan "boleh" juga memberikan kenyamanan pada mitratutur karena dapat menentukan pilihan dan tidak ada unsur paksaan atau keharusan. Pada wacana percakapan 18 pematuhan terhadap prinsip kebijaksanaan ditandai dengan penggunaan kata "maaf" dan "gmn" (bagaimana). Dalam konteks kata wacana tersebut penggunaan kata "maaf" secara implistit bertujuan untuk memberikan penghargaan terhadap mitratutur yang dihormati. Ungkapan tersebut juga memberikan kenyamanan kepada mitratutur karena merasa dihargai. Sementara penggunaan kata "gmn" (bagaimana) menunjukkan kerendahhatian dari penutur sekaligus permintaan yang diperhalus. Dalam pengertian yang lain penutur berusaha menghormati mitratutur dengan cara meminta respon yang memungkinkan mitratutur untuk memilih. Ungkapan serupa juga digunakan mahasiswa dalam wacana 19. Pematuhan terhadap prinsip kebijaksanaan terlihat dari pemberian informasi penutur kepada mitratutur dan pemberian kesempatan bagi mitratutur untuk mengambil keputusan dengan menggunakan kata "gmna" (bagaimana). Dalam wacana lain penelitian ini yang menunjukkan adanya pematuhan terhadap prinsip kebijaksanaan ditandai juga dengan upaya untuk menguntungkan mitratutur dan memberikan informasi yang tidak merugikan orang lain.

\section{b. Pematuhan Prinsip Kedermawanan}

Pematuhan terhadap prinsip kedermawanan mahasiswa terhadap dosen dalam wacana komunikasi berbasis jejaring sosial WhatsApp ditandai dengan upaya untuk memperbesar kerugian bagi diri sendiri dan memperkecil keuntungan orang lain. Berikut adalah beberapa bentuk komunikasi antara mahasiswa dan dosen yang menunjukkan adanya pematuhan terhadap prinsip kedermawanan.

[20] Mahasiswa : "Malam miss, nammo buddhaya. Miss, mau tnya peminjamannya ini saja atau ada yg perlu ditmbahkan miss. Untuk ruangannya pinjam yang ruangan mana saja miss."

Dosen

: "NB.. kursi gk usahh....smua duduk di karpett." 
[21] Dosen

Mahasiswa

[22] Mahasiswa

\section{dhamma no 17."}

: "Oke. Pak.." "Mau bawa k ruangan Bapak???"

: "Selamat siang bu, makalah dan slide ppt saya sudah saya kirim ke email atas nama umi adhanna." "Saya mohon sekiranya dapat dicheck, agar bila ada kesalahan atau ketidaksesuaian mareri dan konteks bisa segera diperbaiki, terimakasih atas waktunya bu, maaf mengganggu."

Dosen : “( ( ) ?

Pada wacana percakapan 20 mahasiswa berusaha memberikan tawaran yang leluasa kepada dosen. Mahasiswa menggunakan kalimat tanya berupa penawaran yang menghasilkan efek berupa tindakan diri sendiri. Artinya, dalam konteks ungkapan "atau ada yg perlu ditmbahkan miss" dan "Untuk ruangannya pinjam yang ruangan mana saja miss" mahasiswa memberikan penawaran kepada kepada dosen untuk kemudian dikerjakan sendiri. Ungkapan tersebut dalam prinsip kedermawanan sering juga disebut sebagai kepedulian dan kemurahhatian. Pada wacana percakapan 21 mahasiswa berusaha menunjukkan sikap hormat, peduli, dan bermurah hati kepada dosen. Ungkapan "mau bawa k ruangan Bapak???" adalah bukti bahwa tawaran yang diberikan oleh mahasiswa sangat leluasa dan tidak menimbulkan kerugian bagi dosen. Penawaran tersebut juga bermakna sebuah pertanyaan yang secara tersirat mengondisikan mahasiswa memperkecil keuntungan bagi dirinya sendiri. Wacana percakapan 22 antara mahasiswa dan dosen juga menunjukkan adanya pematuhan prinsip kedermawanan. Ungkapan "mohon kiranya" menjadi petunjuk yang jelas bahwa mahasiswa tersebut memberikan penghormatan untuk pesan utama yang hendak disampaikan, yaitu permohonan. Sebanyak 24 wacana percakapan lainnya yang menunjukkan adanya pematuhan terhadap prinsip kedermawanan juga mengandung ungkapan seperti kepedulian, kemurahan hati, dan penghormatan kepada mitratutur.

\section{c. Pematuhan Prinsip Penghargaan}

Pematuhan terhadap prinsip penghargaan dalam wacana komunikasi berbasis jejaring sosial WhatsApp ditandai dengan upaya untuk memperbesar pujian bagi orang lain dan memperkecil kritik bagi orang lain. Berikut adalah beberapa bentuk komunikasi antara mahasiswa dan dosen yang menunjukkan adanya pematuhan terhadap prinsip penghargaan.

[23] Dosen

Mahasiswa

$$
\begin{aligned}
& \text { :"Wahh dibajak status ini." } \\
& \text { :"wkwkkwkw" } \\
& \text { Iyh pak terinspirasi dgn pak sabar." } \\
& \text { :"Terima kasih bos BEM." } \\
& \text { :"Samasama pak bos perpus." }
\end{aligned}
$$

[24] Dosen

Ada dua ungkapan yang menunjukkan pematuhan terhadap prinsip penghargaan yaitu "terinspirasi" pada data 23 dan "pak bos" pada data 24. Kedua ungkapan tersebut menunjukkan pujian yang tulus kepada orang lain yang berupa kekaguman, penghormatan, dan penghargaan. Ungkapan tersebut memberikan kesenangan kepada mitratutur karena bukan ungkapan yang berisi cacian, celaan, dan fitnah. Keterbatasan jumlah pematuhan terhadap prinsip penghargaan merupakan hal yang wajar karena wacana komunikasi yang dikaji sebagian besar berkaitan dengan wacana akademis. Tujuan komunikasi banyak berpusat pada konsultasi materi, pengaturan jadwal kuliah, pembimbingan, dan kegiatan akademik di luar kampus sehingga peluang munculnya pujian atau celaan dari penutur terhadap mitratutur sangat kecil.

\section{d. Pematuhan Prinsip Kesederhanaan}

Pematuhan prinsip kesederhanaan dalam wacana komunikasi tulis ditandai dengan upaya untuk memperbesar kritikan pada diri sendiri dan memperkecil pujian bagi diri sendiri. Jika pematuhan prinsip penghargaan berfokus pada orang lain maka pada prinsip kesederhanaan fokusnya adalah diri sendiri. Berikut adalah beberapa bentuk komunikasi antara mahasiswa dan dosen yang menunjukkan adanya pematuhan terhadap prinsip kesederhanaan.

[25] Mahasiswa : "Baik miss. Nnti saya susun miss. Trs kriterianya itu saya sama ian menyiapkan 4 penilaian miss, besok saya beritahukan ke miss iin lagi. Dan mohon koreksinya miss"

Dosen

[26] Dosen : "Okok"

[27] Mahasiswa : "Selamat malam pak, sotti hotu, ini saya Raka pak, pak, saya mau Tanya bsk kan harusnya jadwal pengambilan KHS ya pak, prosedurnya gmana ya pak? Terimakasih, sotti hotu."

Dosen : "Selamat malam. Sotthi hotu. Datang $\mathrm{k}$ kampus. Bagian subbag akademik"

Pada data 25 penanda pematuhan prinsip kesantunan terdapat pada ungkapan "Dan mohon koreksinya miss". Kata "mohon" dalam ungkapan tersebut menunjukkan kerendahhatian dari seorang penutur. Ungkapan tersebut juga memberi makna bahwa penutur tidak mengetahui derajat kebenaran dari pekerjaan yang akan dilakukan sehingga meminta pertimbangan orang lain. Tentu nilain rasa wacana tersebut akan berbeda jika mahasiswa hanya berhenti pada ungkapan "besok saya beritahukan ke miss iin lagi..”. Jika berhenti pada ungkapan tersebut artinya mahasiswa merasa mampu untuk melakukan pekerjaan sendiri tanpa bantuan orang lain. Pada data 26 ungkapan "SebentR pak saya takut salah" dapat dijadikan penanda pematuhan terhadap prinsip kesederhanaan. Ungkapan tersebut menyiratkan makna kerendahhatian dari seorang penutur kepada mitratuturnya. Ungkapan tersebut juga merupakan ekspresi kejujuran dan secara tidak langsung mengandung unsur permintaan kepada mitratutur untuk dapat membantu menyelesaikan. Hal ini sejalan dengan ciri pematuhan prinsip kesederhaan yaitu menunjukkan kelemahan diri sendiri dan tidak memamerkan kelebihan diri sendiri kepada orang lain. Wacana 27 juga menunjukkan kerendahhatian dengan cara menunjukkan kekurangan yang dimiliki kepada orang lain dan meminta 
Iurral Perdiditken Bahasa den Sastra Indonesia
petunjuk sehingga tidak terkesan sombong. Ungkapan
"prosedurnya gmana ya pak?" adalah penanda bahwa penutur meminta saran dari mitratutur yang dianggap mengetahui jawaban yang dibutuhkan.

\section{e. Pematuhan Prinsip Kecocokan}

Pematuhan prinsip kecocokan ditandai dengan upaya untuk memperbesar penyesuaian diri dengan orang lain dan memperkecil ketidaksesuaian diri sendiri dengan orang lain. Pematuhan terhadap prinsip kecocokan merupakan salah satu yang paling banyak dijumpai dalam wacana komunikasi dosen dan mahasiswa. Berikut adalah beberapa bentuk komunikasi antara mahasiswa dan dosen yang menunjukkan adanya pematuhan terhadap prinsip kecocokan.

[28] Dosen : "Jangan lupa dir Karena ikut hikmahbudi $\Theta$

Mahasiswa

: "Maksudnya pak?"

Dosen

: "Belajar bro

Semangat belajarnya jangn kendorrr d. 9 . 9 "

Mahasiswa : "Iya pak, saya tetap harus fokus belajar"

Dosen : "Sip"

[29] Mahasiswa : "Namo buddhaya mr. nomor serial dapat dari mana ya?"

Dosen

: "di crack aja, kana da crack nya, atau baca petunjuknya yang notepad"

Mahasiswa : "Di notepad disuruh emak atau telp $\mathrm{mr}$ Kirim email telp langsung ya"

Dosen

: "Oh bukan jangan Biasanya abis install copy cracknya ke folder macromedia gitu di program file"

Mahasiswa : "Nanti saya coba pak"

Dosen : :Iya.. atau double click cracknya kali"

Mahasiswa : "iya mr terima kasih"

[30] Mahasiswa : "Saya liat d persyaratannya wajib buat power point kan?"

"Lalu, apakah jumlah slide didalam power point menjadi aspek penilaian?"

Dosen : "Mf.. tanyakan ke panitia langsung yaa yg lbih mnguasai aspek penilaian"

Mahasiswa : "Baik, terimakasih bu, maaf mengganggu waktunya"

Pada wacana komunikasi 28 terlihat bahwa penutur memaksimalkan persetujuan dengan mitratutur yang ditunjukkan dengan adanya kesepakatan terhadap hal yang disampaikan oleh mitratutur. Ungkapan "Iya pak, saya tetap harus fokus belajar" menjadi penanda bahwa mahasiswa tersebut menyetujui saran yang diberikan oleh dosen. Dosen meminta mahasiswa untuk tidak larut dalam kegiatan keagamaan yang diikuti mahasiswa tetapi tetap harus fokus pada kegiatan akademik di kampus. Pada wacana komunikasi 29 juga menunjukkan upaya menghindari pendapat yang bertolak belakang antara penutur dan mitratutur. Dalam konteks wacana komunikasi tersebut mahasiswa mencoba bertanya kepada dosen dan dosen berusaha menjelaskan kepada mahasiswa tersebut. Ungkapan "Nanti saya coba pak" menjadi penanda bahwa mahasiswa tersebut menyatakan persetujuan dan mengikuti instruksi dari dosen. Penegas persetujuan yang menunjukkan adanya pematuhan terhadap prinsip kecocokan adalah ungkapan "iya mr terima kasih". Ungkapan tersebut semakin mempertegas kesesuaian antara penutur dan mitratutur. Pematuhan terhadap prinsip kecocokan juga dapat dilihat pada wacana komunikasi 30. Ungkapan "Baik, terimakasih bu, maaf mengganggu waktunya" menunjukkan upaya mahasiswa untuk menyetujui apa yang disarankan oleh dosen. Penanda lain dalam pematuhan prinsip kecocokan adalah menghindari kepentingan yang tidak ada hubungannya dengan pokok masalah yang dibicarakan dengan cara memberikan pendapat atau kritik dengan santun. Itulah yang terlihat dalam wacana komunikasi lain yang memunuhi kriteria pematuhan prinsip kecocokan.

\section{f. Pematuhan Prinsip Kesimpatian}

Pematuhan prinsip kesimpatian ditandai dengan upaya penutur untuk memperbesar simpati dan memperkecil antipasti pada mitratutur. Beberapa indikator pematuhan prinsip kesimpatian antara lain ikut serta merasakan perasaan orang lain dalam bentuk memberikan ucapan selamat dan terampil memahami perasaan orang lain. Berikut adalah beberapa bentuk komunikasi antara mahasiswa dan dosen yang menunjukkan adanya pematuhan terhadap prinsip kesimpatian.

[31] Dosen

: "Deni.. Anjali malah saki ... sy lg minta tolong gantiin P. Nyoto dlu siapa tau mau"

Mahasiswa

[32] Dosen

: "Ooo ok Miss gws yah buat Anjali 1 , : "@Happy birthday mamas Eka@" (status WhatsApp)

Mahasiswa : "Habede yah Eka Ayu Vanno Sukham Balam d

Pada wacana komunikasi 31, pematuhan prinsip kesimpatian ditandai dengan penggunaan ungkapan "Ooo ok Miss gws yah buat Anjali : $\mathbb{N}$ ". Makna ungkapan tersebut adalah mendoakan agar cepat sembuh dari sakit. Ungkapan tersebut juga sebagai penanda bahwa mahasiswa turut serta merasakan perasaan orang lain dalam bentuk ucapan doa. Ungkapan tersebut timbul berdasarkan penilaian perasaan diri sendiri kepada orang lain. Wacana 32 juga menunjukkan adanya pematuhan prinsip kesimpatian. Jika pada wacana 31 mahasiswa menyampaikan doa untuk mengungkapkan kesimpatian, pada wacana 32 mahasiswa menyampaikan selamat untuk mengungkapkan kesimpatian. Penanda yang jelas terlihat dalam konteks komunikasi tersebut adalah "Habede yah Eka Ayu Vanno Sukham Balam d.". Maksud dari ungkapan tersebut adalah "selamat ulang tahun semoga mendapatkan berkah kebahagiaan". Ungkapan seperti itu jelas membuat mitratutur merasa simpati karena merasa diperhatikan.

\section{PENUTUP}

Berdasarkan hasil penelitian dan pembahasan di atas dapat diambil simpulan bahwa gaya bahasa dalam wacana komunikasi mahasiswa terhadap dosen berbasis jejaring sosial WhatsApp dari aspek gramatikal antara lain elipsis dan kata depan unik, aspek leksikal antara lain language mixing dan bahasa gaul, aspek grafologi antara lain clipping, sound addition, dan coinage. Pematuhan terhadap prinsip kesantunan 
dalam wacana komunikasi mahasiswa terhadap dosen berbasis jejaring sosial WhatsApp meliputi pematuhan terhadap prinsip kebijaksanaan, kedermawanan, penghargaan, kesederhanaan, kecocokan, dan kesimpatian.

Berdasarkan simpulan penelitian dan melihat kondisi kesantunan berbahasa mahasiswa terhadap dosen, mahasiswa hendaknya dapat menggunakan bahasa yang santun dalam berkomunikasi dengan dosen baik melalui bahasa lisan maupun bahasa tulis. Dosen hendaknya dapat menjadi teladan bagi mahasiswa dalam menggunakan bahasa tulis yang baik dalam wacana komunikasi berbasis jejaring sosial WhatsApp. STABN Sriwijaya juga hendaknya membuat regulasi mengenai etika berkomunikasi melalui jejaring sosial bagi warga kampus.

\section{DAFTAR PUSTAKA}

Adriana, Iswah. (2014). Analisis Bahasa SMS Mahasiswa STAIN Pamekasan Terhadap Dosen Menurt Prinsip Kesantunan Leech. Jurnal Nuansa, Vol. 11 Nomor 1 Januari - Juni 2014, hlm. 53-76.

Al Amin. (2015). SMS Kurang Ajar Mahasiswa Bikin Kita Senyum-Senyum: (Online) diakses dari https://www.merdeka.com/peristiwa/sms-kurang-ajarmahasiswa-ke-dosen-bikin-kita-senyum-senyum.html pada 16 Februari 2018.

Brown dan Levinson. (2010). Kesantuan Berbahasa. Jakarta: Rineka Cipta.

Hermawan, Budi. (2013). Multimodality: Menafsir Verbal, Membaca Gambar, dan Memahami Teks. Jurnal Pendidikan Bahasa dan Sastra, Volume 13 Nomor 1, hlm. 22-31.

Karimah, El Kismiyati dan Uud Wahyudin. (2010). Filsafat dan Etika Komunikasi. Bandung: Widya Padjadjaran.

Leech, Geoffrey. (2015). Principle of Pragmatics. Terjemahan ke dalam Bahasa Indonesia oleh Oka. Jakarta: UI Press.

Markhamah, dkk. (2011). Analisis Kesalahan dan Kesantunan Berbahasa. Surakarta: Muhammadiyah University Press.

Moleong, Lexy J. (2013). Metode Penelitian Kualitatif. Bandung: Remaja Rosdakarya.

Rahardi, Kunjana. (2005). Pragmatik: Kesantunan Imperatif Bahasa Indonesia. Jakarta: Erlangga.

Ralie, Zoraya. (2017). Etiket Mahasiswa terhadap Dosen: (Online), diakses dari https://beritagar.id/artikel/gayahidup/etiket-mahasiswa terhadap-dosen tanggal 16 Februari 2018.

Watie, Errika Dwi Setya. (2011). Komunikasi dan Media Sosial. Jurnal The Messenger, Volume III, Nomor 1, Edisi Juli 2011. 